\title{
〔第45回総会シンポジウム 一脳神経核医学検査の技術的問題点一〕
}

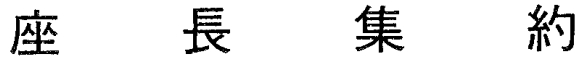

藤田透

京都大学医学部附属病院

\section{1.はじめに}

「脳神経核医学」は「心臓核医学」に代って今最も注目 を集めている分野である。これは新しいトレーサの登場 とPET，SPECT といった断層技術の進歩によるところ が大きい。1986年, Becquerel がウラン鉱石のフィルム感 光作用を発見して以来 90 年の歴史をみると, 測定器の開 発と新しい核医学手法（トレーサ）の開発がよく一致し て発展してきている。脳神経領域における核医学検查の 発展は三つの時代に分けることができる。第I期は1953 年 Moor による ${ }^{131} \mathrm{I}$-HSA に始まる脳スキャンの時代で ある。本法により初めて脳疾患の画像化が可能となり， その後 X 線 CT 装置が出現するまで ${ }^{99 \mathrm{~m}} \mathrm{TcO}^{-}{ }_{4}$ (Harper：1964年) 等を用いた本法が脳の画像診断では 重要な役割を果した。第II期は1960年代からのLassen らによる ${ }^{85} \mathrm{Kr} ，{ }^{133} \mathrm{Xe}$ を用いた局所脳血流量 $(\mathrm{rCBF})$ 測 定の時代である。本法はKety らによる $\mathrm{N}_{2} \mathrm{O}$ を用いた全 脳血流量測定に代って，現在におうても種々の rCBF 測 定法の golden standard (定規) として高く評価されてい る。第III期は1980年代の PET，SPECT の時代である。 本法は核医学検査本来の特徵である機能診断を三次元画 像として可能とし，他の診断モダリティではできない脳 神経領域における大きな分野を築こうとしている。

こうした背景の中で今回のシンポジウムが企画された 訳であるが，脳神経領域における核医学検査には多くの トレーサを用いた多くの検査法がある。今回のシンポジ ウムではその全てについて討論できず，その中から現在 最も注目されているものに限定してテーマを選び，最も 相応しい方にシンポジストとして願いした。

\section{2. 古くて新しい局所脳血流量測定法}

${ }^{133} \mathrm{Xe}$ クリアランス法は核医学の特徴をうまく利用し た優れた定量測定法であり，開発後 20 年以上経過した現 在も広く利用されている。頭初は頸動脈内注入法であっ たのが静注法, 吸入法と非侵襲的方法に改良することで スクリーニング検相としての実施を可能とし，测定装置
もシングルプローブ形からマルチプローブ形, SPECT 形へと発展した。中村幸夫先生（大阪大学）にはこの方 法のもつ技術的な問題点を中心に検討をお願いした。虚 血部における測定精度，脳血液分配係数の選択，start fitting point，感度・分解能の限界，呼気放射能補正等の 諸問題を含んでおり，また現在の装置ではこれらがブラ ックボックスとなっているために測定法の十分な理解が

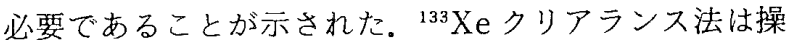
り返し検査が可能なことなど利点が多く， rCBF 測定法 の定規として今後共利用されるであろう.また, ${ }^{123}$ I-IMP などによる $\mathrm{CBF}$ 測定は， ${ }^{133} \mathrm{Xe}$ 法と比較して画質が優れ て扝り，絶体值としての測定よりも $\mathrm{CBF}$ の分布画像と して多用される検査となろう。

\section{SPECT 像の画質改善}

本邦に扔いて SPECT 装置が本格的な稼動を始めて 10 年になる。その間，特に脳のSPECT 像の画質は隔世の 進歩をしたが，まだ全てに満足できる訳でない，種々の 疾患を診断する上でSPECT 像が最も必要な情報を含ん でいながら，他の診断画像を越えることができない理由 は画質にある.SPECT 像の画質改善に向けて,ハードウ エア面からの検討を福喜多博義先生（国立がんセンタ） に打願いした。画質改善のためには分解能と感度を向上 させることが必要と述べ，そのための方法が示された。 第一はSPECT 専用装置または多検出器形ガンマカメラ の利用である. 10 年前 $20 \mathrm{~mm}$ であった分解能は近接収集 では12 mm と改善され, また最近の頭部専用 SPECT 装 置では $7 \mathrm{~mm}$ にまで向上して, 脳血流画像では PET 像 と大きな遜色はなくなってきた。第 2 の方法としては特 殊コリメー夕の利用で，特にファンビームあるいはコ一 ンビームコリメータの利用が有望視される。更に, 収集 方法の選択や装置の精度管理も画質改善のために大きな 意昧を持つ。

SPECT 像は収集した投影データから画像再構成され て得られる画像であり，画質改善のためにはソフトウエ アの占める役割も大きい。この面汃らの検討を細羽実先 
生（島津製作所）にお願いした，第一の問題は最適フィ ルタの選択で，これは信号量の少ない SPECT 法独自の 悩みである.プレフィルタの有効性，ハード化によるリ アルタイム処理の必要性が示された，第二は吸収補正の 問題で，SPECT 法ではいずれの方法にも一長一短があ り正確な補正は原理的に不可能である。脳の場合，頭骨 の補正の有無により灰白質の SPECT 值は30\%の違いが 生じること, 将来的には二核種収集補正法による改善の 可能性が示された，第三は散乱補正の問題で，新しい補 正法として EWA (energy weighted acquisition) 法が 紹介された. ${ }^{99 m} \mathrm{~T} c よ り も{ }^{201} \mathrm{Tl}$ 等の低エネルギー核種で 効果が大きく，リアルタイム処理が可能なことから期待 が持てそうである。いずれの問題も，計算時間に関して はコンピュータの進歩により近い将来解決できるであろ う. 処理方法については，メーカによるシミュレーショ ン結果から導いた方向付けを望みたい。

\section{4. 望まれる SPECT 画像の標準化}

「科学技術」とは「一様化」の技術と言われる。しか し, SPECT 画像, ことに脳の SPECT 画像は施設間差が 大きい. 三塩宏二先生（埼玉県立がんセン夕）にはこの 問題解決のための糸口を探っていただいた，SPECT 像 の標準化において, 表示法については日本アイソトープ 協会イメージング規格化委員会の勧告があり，画質の標 準化について多機種間で検討していただいた.SPECT 像の画質は基本的にはハードウエアへの依存が大である が，同種の装置ではソフトウエアによる要因が大きい. 画像サイズ，表示技術が装置間で不統一なことの他，ソ フトウエアのバージョンアップができていないこと，同 じフィルタ処理をしてもパラメータが装置間で不統一な こと等の問題が大きいと指摘した. ディジタルファント ムを用いたシミュレーションによる画像処理方法の最適 化が SPECT 画像の標準化の近道と提案した.

\section{PET 検査の定量性を保つために}

今の脳神経領域における核医学検查の発展は, PET 装 置を用いたサイクロトロン核医学の進歩が起爆剤となっ ている. PET 梚査の特徵は, (1) ${ }^{11} \mathrm{C} \cdot{ }^{13} \mathrm{~N} \cdot{ }^{15} \mathrm{O} \cdot{ }^{18} \mathrm{~F}$ とい った生体構成元素または類似核種の使用により人の生 理・生化学マッピングができること, (2)同時計数により 分解能执よび定量性の高い画像が得られることにある. PET 装置の多くは約 1000 個の BGO 検出器を持ってお り，この定量性を保つには相当な苦労が課せられる。測 定上，管理上の問題について，庄司安明先生（秋田脳血
管研究センタ)に担当していただいた。特にPET 装置の 日常管理上の問題について，(1)検出器感度補正デー夕は 毎日測定, (2)吸収補正データは検査毎測定, (3)ウエルカ ウンタのエネルギーウィンド確認は毎日測定, (4) PET とウエルカウンタとの較正は毎週測定することにより 2 \%以内の変動に保てると述べた。現在，日本において本 格的に PET 検査を実施しているのは 9 施設, 1 年以内 には更に 4 施設が加わるが，将来的にはサイクロトロン を持たなくても PET 装置のみで検査が可能となること が考えられ，多く施設で身近な問題となる.

\section{6. 核医学検査の貢献度は今}

種々の診断モダリティーがある中で，核医学検査はど れ程貢献しているか，これは検査を実施していく上で気 になる問題である。多くの診断法における核医学検査の 位置付け，将来性について，脳神経外科医の立場から藤 江博先生（富永記念病院）に担当していただいた．脳血 管障害例における ${ }^{133} \mathrm{Xe}$ 法と IMP 法, HM PAO 法の有 用性について述べ, IMP 法の夕イプ分類による病期や予 後診断の可能性, HM PAOの二回投与によるダイアモ ックス負荷法を紹介し, 核医学検査が補助的検查加ら術 前・術後の不可欠な検査法となりつつあることが示され た．脳腫湯例においてはトレーサの組み合わせによる組 織診断, 再発・治療効果判定の有用性, 精神・神経疾患 におけるフロートレーサの有用性が示された。核医学検 査の将来性としては脳代謝診断法としての確立が必要で, そのためには PET 検査の SPECT 検査への還元, 即ち 代謝測定用トレーサの必要性が討論を通して示された。

\section{7.おわりに}

核医学検查の進歩は, 放射性医薬品と測定装置（開発 プログラム）の開発であり，これを支えるのが検査法， 検査技術である．現在の PET, SPECT 法の進歩は正に これらがうまくかみ合って成されたものである，どの検 查法をとってみても，ハードウエア・ソフトウエアが進 歩するほど，品質管理を始めとする使用法を確立させて おく必要がある．画像はディジタル化され作る要素が大 きくなってきた今，ますますこの面での努力が必要とな つて来よう.また, SPECT 画像の標準化については早期 に本学会で取り組む必要がある。

最後に至適なテーマを与えていただきました山田学会 長, 後藤大会会長始め関係役員の方々，また一年間に渡 りご努力いただいたシンポジストの方に感謝します。 